\title{
Prevalence of Antibiotic Resistance Genes in Subjects with Successful and Failing Dental Implants. A Pilot Study
}

\author{
Georgios Koukos ${ }^{1, *}$, Christos Papadopoulos ${ }^{2}$, Lazaros Tsalikis ${ }^{2}$, Dimitra Sakellari ${ }^{2}$, Minas Ar- \\ senakis $^{3}$ and Antonios Konstantinidis ${ }^{2}$
}

\author{
${ }^{1} 251$ General Air Force Hospital, Department of Periodontology, Athens, Greece \\ ${ }^{2}$ Department of Preventive Dentistry, Periodontology and Implant Biology, Dental School, Aristotle University of Thes- \\ saloniki, Thessaloniki, Greece \\ ${ }^{3}$ Department of Genetics and Molecular Biology, School of Biology, Aristotle University Thessaloniki, Thessaloniki, \\ Greece
}

\begin{abstract}
Objectives: To investigate the prevalence of the bacterial genes encoding resistance to beta-lactams, tetracyclines and metronidazole respectively, in subjects with successful and failing dental implants and to assess the presence of Staphylococcus aureus and the mecA gene encoding for Methicillin Resistant Staphylococcus aureus (MRSA) in the same samples.

Materials and Methodology: The subject sample included 20 participants with clinically healthy osseointegrated implants and 20 participants with implants exhibiting peri-implantitis. Clinical parameters were assessed with an automated probe, samples were collected from the peri-implant sulcus or pocket and analyzed with Polymerase Chain Reaction for $b a_{\mathrm{TEM}}$, tet $M$, tet $Q$ and nim genes, S. aureus and MRSA using primers and conditions previously described in the literature.

Results: Findings have shown high frequencies of detection for both groups for the tetracycline resistance genes tetM $(>30 \%)$, tetQ $(>65 \%)$ with no statistical differences between them (z-test with Bonferroni corrections, $p<0.05)$. The $b l a_{\mathrm{TEM}}$ gene, which encodes resistance to beta-lactams, was detected in $<15 \%$ of the samples. The nim gene, which encodes resistance to metronidazole, S.aureus and the mecA gene encoding for MRSA were not detected in any of the analyzed samples.

Conclusions: Healthy peri-implant sulci and peri-implantitis cases often harbor bacterial genes encoding for resistance to the tetracyclines and less often for beta-lactams. Thus, the antimicrobial activity of the tetracyclines and to a lower extent to beta-lactams, might be compromised for treatment of peri-implantitis. Since no metronidazole resistance genes were detected in the present study, its clinical use is supported by the current findings. S.aureus may not participate in periimplant pathology.
\end{abstract}

Keyword: Dental implants, antibiotics, bacterial resistance genes, peri-implantitis.

\section{INTRODUCTION}

Dental implants are currently considered as an excellent alternative solution for replacing teeth.

When evaluating the performance of dental implants it should be mentioned that implant survival is no longer a reliable parameter for clinical outcome and instead it is of outmost importance that the dental implants remains free from functional and aesthetic complications, a parameter known as implant success.

A number of systematic reviews have shown that although implant survival rates can reach after 10 years $89.4 \%$

*Address correspondence to this author at the Department of Periodontology, 251 General Air Force Hospital, Athens, Greece;

Tel: 0030 6983520282; E-mail:gkoukos@dent.auth.gr for single tooth restorations and $93.9 \%$ for prosthesis in partially edentulous subjects, the rate of complications can reach $33.6 \%[1,2]$.

The incidence of per-implantitis as reported in clinical studies depends on definition of the disease [3, 4]. The similarity in bacterial pathogens associated with periodontitis and peri-implantis, currently suggest a common microbial aetiology [5]. In addition to the bacterial factor "a number of other parameters such as poor integrity of the connection between the implant and the abutment" the iatrogenic introduction of cement in the peri-implant area and the practicioner's choice and clinical management of implant design have also been shown to influence the initiation and progression of periimplantitis [6].

The goal of treating peri-implantitis is to regenerate bone and achieve new osseointegration. Various approaches have 
been applied for treating both peri-implant mucositis and peri-implantitis, based on the concept they are both infectious diseases. According to the current evidence, it is suggested that non-surgical therapy leads to unpredictable outcomes, although in some cases it has been shown that adjunctive antibiotics might assist in resolution of periimplantitis [7-9]. Surgical treatment for treating periimplantitis has also been applied, using various techniques with or with out adjunctive antimicrobials [10]. Again, based on the current evidence, no definite clinical guidelines can be extrapolated, especially regarding the role of systemic or local antimicrobials, which could lead to predictable therapeutical outcomes.

The administration of antimicrobials is globally compromised by the growing phenomenon of antimicrobial resistance [11]. Due to the over- or mis- use of antibiotic compounds worldwide, several classes of antibiotics, including the ones administered for oral infections, can now be ineffective against various bacterial species, due to dissemination of antibiotic resistance, which is frequently spread by genetic material and is favored in the oral environment due to the biofilm nature of bacterial deposits $[12,13]$.

Therefore, the recognition of specific genes which encode for mechanisms of resistance to various antibiotics, might have clinical significance, by guiding the clinicians in a personalized choice and prescription of specific antimicrobials.

Aim of the current pilot study was to investigate the prevalence of bacterial genes encoding for antimicrobial resistance against classes of antibiotics commonly used for treatment of peri-implantitis in healthy and diseased periimplant sulci. The presence of S.aureus and the Methicillin Resistant Staphylococcus aureus (MRSA) was also assessed in the same samples.

\section{MATERIALS AND METHODOLOGY}

\section{Subject Sample and Study Design}

Differences between groups regarding the prevalence of investigated resistance genes was set as the primary outcome of the present study [14]. The experiment was set to have at least $80 \%$ power to detect differences of $25 \%$ with a significance level (a) of 0.05 (two-tailed). Therefore 20 subjects were required for each group (Statmate ${ }^{\circledR}, \mathrm{GraphPad}$ Inc,San Diego,CA,USA)

The study was conducted according to the protocol outlined by the Research Committee, Aristotle University of Thessaloniki, Greece and approved by the Ethical Committee of the School of Dentistry (\#120), in compliance with the ethical principles of the World Medical Association Declaration of Helsinki. All patients read and signed an appropriate informed consent document prior to the participation in the study.

\section{Inclusion Criteria}

To be included in the study, subjects should fulfill the following criteria: a) age $>30$ years.

b) absence of systemic diseases or medications known to affect periodontal tissues, infectious conditions (hepatitis, HIV) or pregnancy and lactation.

c) no periodontal treatment or antibiotic intake during the last six months.

In addition participants should fulfill one of the following conditions:

a) subjects with periodontal health (bleeding on probing $<10 \%$, without any clinical attachment loss $>3 \mathrm{~mm}$ ) and a single osseointegrated implant present for at least 5 years in the dentition with probing depth $<3 \mathrm{~mm}$, without any clinical attachment loss on the site of the implant and no bleeding on probing .

b) subjects at the supportive periodontal therapy phase , treated at least 5 years ago and exhibiting a single implant present for at least 5 years in the dentition with peri-implantitis (bleeding on probing/suppuration and probing depth $>6 \mathrm{~mm}$ or bone loss $>2.5 \mathrm{~mm}$ on the implant) [3].

\section{Clinical Recordings}

Clinical recordings were performed at six points of all teeth present at the dentition (mesio-buccal, buccal, distobuccal, mesio-lingual, lingual, distolingual). Recordings were performed by a calibrated examiner (GK) using an automated probe (Florida probe, Florida Probe Corporation, Gainesville, FL, USA) and included the following parameters:
a) Probing Pocket Depth
b) Recession
c) Clinical Attachment Level
d) Bleeding on Probing

\section{Clinical Sampling}

Samples were taken from healthy and peri-implantitis sites, with sterile paper points left in the sulcus for $30 \mathrm{sec}-$ onds, after removing supragingival plaque with sterile Gracey curettes. All samples were immediately placed in 200 $\mu 1$ of TE buffer (Tris HCL $10 \mathrm{mM}$, EDTA $1 \mathrm{mM}, \mathrm{pH}$ 7.5) and stored at $-20^{\circ} \mathrm{C}$, until assayed.

\section{Polymerase Chain Reaction (PCR)}

Analysis of samples was performed blindly (coded samples). All experiments were performed in the Department of Microbiology, School of Biology, Aristotle University of Thessaloniki, Greece.

The main methodology applied for analysis of samples was Polymerase Chain Reaction (PCR). First of all, PCR was performed for the detection of the $16 S$ ribosomal RNA gene, in order to verify that the clinical samples contained identifiable bacterial DNA [15]. Samples were further analyzed by PCR for the presence of the tetM, tet $Q$, bla $a_{\mathrm{TEM}}, \mathrm{nim}$, nuc and mecA genes. All experiments were run with PCR 
Table 1. Polymerase Chain Reaction (PCR) primers used in the study.

\begin{tabular}{|c|c|}
\hline & PCR Primers \\
\hline \hline $16 S$ & 5'-CAG GAT TAG ATA CCC TGG TAG TCC ACG C-3' and 5'- GAC GGG CGG TGT GTA CAA GGC CCG GGA ACG-3' [15] \\
\hline$t e t M$ & 5'-GAC ACG CCA GGA CAT ATG G-3' and 5'-TGC TTT CCT CTT GTT CGA G-3' [16] \\
\hline$t e t Q$ & 5'-GGC TTC TAC GAC ATC TAT TA- 3' and 5-CAT CAA CAT TTA TCT CTC TG-3' [17] \\
\hline bla $a_{\mathrm{TEM}}$ & 5'-AGATCAGTTGGGTGCACGAG -3'and 5'-CAGTGCTGCAATGATACCGC -3' [18] \\
\hline nim & 5'-ATG TTC AGA GAA ATG CGG CGT AAG CG-3 and 5'-GCT TCC TTG CCT GTC ATG TGC TC-3' [19] \\
\hline$n u c$ & 5'-TCAGCAAATGCATCACAAACAG-3' and 5'-CGTAAATGCACTTGCTTCAGG-3' [20] \\
\hline$m e c A$ & 5'-GGGATCATAGCGTCATTATTC-3' and 5'-AACGATTGTGACACGATAGCC-3 [21] \\
\hline
\end{tabular}

Table 2. Polymerase Chain Reaction (PCR) conditions.

\begin{tabular}{|c|c|c|c|c|c|c|c|}
\hline PCR Conditions & $16 S$ & tetM & tet $Q$ & $b^{\prime a} a_{\text {TEM }}$ & nim & nuc & mecA \\
\hline Initial denaturation & $95^{\circ} \mathrm{C}$ for $5 \mathrm{~min}$ & $95^{\circ} \mathrm{C}$ for $5 \mathrm{~min}$ & $95^{\circ} \mathrm{C}$ for $5 \mathrm{~min}$ & $94^{\circ} \mathrm{C}$ for $10 \mathrm{~min}$ & $\begin{array}{c}94^{\circ} \mathrm{C} \text { for } \\
10 \mathrm{~min}\end{array}$ & $94^{\circ} \mathrm{C}$ for $10 \mathrm{~min}$ & $94^{\circ} \mathrm{C}$ for $10 \mathrm{~min}$ \\
\hline Denaturation & $94^{\circ} \mathrm{C}$ for $1 \mathrm{~min}$ & $\begin{array}{l}94^{\circ} \mathrm{C} \text { for } \\
30 \mathrm{sec}\end{array}$ & $\begin{array}{c}94^{\circ} \mathrm{C} \text { for } 30 \\
\text { sec }\end{array}$ & $94^{\circ} \mathrm{C}$ for $1 \mathrm{~min}$ & $94^{\circ} \mathrm{C}$ for $30 \mathrm{~s}$ & $94^{\circ} \mathrm{C}$ for $30 \mathrm{~s}$ & $94^{\circ} \mathrm{C}$ for $30 \mathrm{~s}$ \\
\hline Step 2 to 4 & 34 cycles & 37 cycles & 37 cycles & 35 cycles & 35 cycles & 35 cycles & 30 cycles \\
\hline Final extension & $72^{\circ} \mathrm{C}$ for $3 \mathrm{~min}$ & $\begin{array}{l}72^{\circ} \mathrm{C} \text { for } \\
10 \mathrm{~min}\end{array}$ & & $72^{\circ} \mathrm{C}$ for $10 \mathrm{~min}$ & $\begin{array}{l}72^{\circ} \mathrm{C} \text { for } \\
10 \mathrm{~min}\end{array}$ & $72^{\circ} \mathrm{C}$ for $10 \mathrm{~min}$ & $72^{\circ} \mathrm{C}$ for $10 \mathrm{~min}$ \\
\hline $\mathrm{MgCl}_{2}$ Solution, $25 \mathrm{mM}$ & $3 \mu \mathrm{l}(1.5 \mathrm{mM})$ & $3 \mu \mathrm{l}(1.5 \mathrm{mM})$ & $3 \mu \mathrm{l}(1.5 \mathrm{mM})$ & $4 \mu \mathrm{l}(2 \mathrm{mM})$ & $3 \mu \mathrm{l}(1.5 \mathrm{mM})$ & $4 \mu \mathrm{l}(1.5 \mathrm{mM})$ & $3 \mu \mathrm{l}(1.5 \mathrm{mM})$ \\
\hline $\begin{array}{l}\text { Upstream Primer, } \\
\qquad 10 \mu \mathrm{M}\end{array}$ & $\begin{array}{c}2.5 \mu \mathrm{l} \\
(0.5 \mu \mathrm{M})\end{array}$ & $\begin{array}{c}2.5 \mu \mathrm{l} \\
(0.5 \mu \mathrm{M})\end{array}$ & $\begin{array}{c}2.5 \mu \mathrm{l} \\
(0.5 \mu \mathrm{M})\end{array}$ & $5 \mu \mathrm{l}(1 \mu \mathrm{M})$ & $5 \mu \mathrm{l}(1 \mu \mathrm{M})$ & $6 \mu \mathrm{l}(1 \mu \mathrm{M})$ & $5 \mu \mathrm{l}(1 \mu \mathrm{M})$ \\
\hline $\begin{array}{l}\text { Downstream Primer, } \\
10 \mu \mathrm{M}\end{array}$ & $\begin{array}{c}2.5 \mu \mathrm{l} \\
(0.5 \mu \mathrm{M})\end{array}$ & $\begin{array}{c}2.5 \mu \mathrm{l} \\
(0.5 \mu \mathrm{M})\end{array}$ & $\begin{array}{c}2.5 \mu \mathrm{l} \\
(0.5 \mu \mathrm{M})\end{array}$ & $5 \mu \mathrm{l}(1 \mu \mathrm{M})$ & $5 \mu \mathrm{l}(1 \mu \mathrm{M})$ & $6 \mu \mathrm{l}(1 \mu \mathrm{M})$ & $5 \mu \mathrm{l}(1 \mu \mathrm{M})$ \\
\hline Taq polymerase, $5 \mathrm{U} / \mu \mathrm{l}$ & $\begin{array}{c}0.25 \mu 1 \\
(1.25 \mathrm{U})\end{array}$ & $\begin{array}{c}0.25 \mu \mathrm{l} \\
(1.25 \mathrm{U})\end{array}$ & $\begin{array}{c}0.25 \mu \mathrm{l} \\
(1.25 \mathrm{U})\end{array}$ & $0.25 \mu \mathrm{l}(1.25 \mathrm{U})$ & $\begin{array}{c}0.25 \mu \mathrm{l} \\
(1.25 \mathrm{U})\end{array}$ & $0.25 \mu \mathrm{l}(1.25 \mathrm{U})$ & $0.25 \mu \mathrm{l}(1.25 \mathrm{U})$ \\
\hline Water for injection & $25.75 \mu \mathrm{l}$ & $25.75 \mu 1$ & $25.75 \mu 1$ & $18.75 \mu \mathrm{l}$ & $20.75 \mu 1$ & $19.75 \mu 1$ & $19.75 \mu 1$ \\
\hline
\end{tabular}

conditions and primers previously reported to the literature and are described in Tables 1 and 2 [15-21].

The tet $M$ and tet $Q$ genes confer resistance to the tetracyclines, the bla $a_{\text {TEM }}$ gene to beta-lactams, and the nim genes to metronidazole. The nuc gene encodes a thermonuclease exclusive for S.aureus, while the mecA gene is characteristic for MRSA.

The final volume of the reaction mixture for each PCR assay was $50 \mu \mathrm{l}$, A Peltier Thermal Cycler (PTC-100, Peltier Thermal Cycler, MJ Research) was used for experiments.
For each set of samples analyzed by PCR a negative and a positive control were used. Sterile water for injection (Demo S.A. Pharmaceutical Industry,Athens,Greece), was used as negative control (replacing DNA template into the PCR reactions). Positive controls included bacterial species positive for the above mentioned bacterial genes [22].

The products of the DNA amplification were electrophoresed through a $2 \%$ agarose gel, stained with ethidium bromide, exposed under UV light and photographed. A 100bp DNA ladder (Invitrogen, Carlsbad, CA, USA) was also 
Table 3. Demographic data of participants.

\begin{tabular}{|c|c|c|c|c|}
\hline Diagnosis & Total & Age $($ mean \pm SD $)$ & Male (\%) & Smokers (\%) \\
\hline $\begin{array}{l}\text { Participants with clinically healthy osseointegrated } \\
\text { implants }\end{array}$ & 20 & $55.2 \pm 8.9$ & 45 & 40 \\
\hline Participants with peri-implantitis & 20 & $55.4 \pm 9.8$ & 60 & 50 \\
\hline
\end{tabular}

No statistically significant differences between groups were observed (Kruskal -Wallis test and z-test with Bonferroni corrections, $\mathrm{p}>0.05$ )

Table 4. Periodontal clinical parameters of the two groups with osseointegrated implants.

\begin{tabular}{|c|c|c|c|c|c|}
\hline & $\mathbf{N}$ & $\begin{array}{l}\text { Probing Depth }(\mathbf{m m}) \\
\qquad(\text { mean } \pm \text { SD })\end{array}$ & $\begin{array}{c}\text { Reseccion } \\
(\text { mean } \pm \text { SD })\end{array}$ & $\begin{array}{l}\text { Clinical Attachment } \\
\text { Level }(\mathrm{mm}) \\
(\text { mean } \pm \text { SD })\end{array}$ & $\begin{array}{c}\text { Bleeding on probing } \\
(\%)\end{array}$ \\
\hline $\begin{array}{l}\text { Participants with clinically healthy } \\
\text { osseointegrated implants }\end{array}$ & 20 & $\begin{array}{l}2 \pm 0.4 \\
\text { (a) }\end{array}$ & $0.1 \pm 0.2$ & $\begin{array}{c}1.6 \pm 0.4 \\
\text { (b) }\end{array}$ & $\begin{array}{c}6 \% \pm 5 \% \\
\text { (a) }\end{array}$ \\
\hline Participants with peri-implantitis & 20 & $\begin{array}{c}3.3 \pm 0.7 \\
\text { (a) }\end{array}$ & $0.4 \pm 0.5$ & $\begin{array}{c}3.7 \pm 0.9 \\
\text { (b) }\end{array}$ & $\begin{array}{c}32 \% \pm 28 \% \\
\text { (a) }\end{array}$ \\
\hline
\end{tabular}

Statistically significant differences between groups are indicated by the same letter (Kruskal -Wallis test and z-test with Bonferroni corrections, $\mathrm{p}<0.05$ )

loaded on agarose gel as a molecular weight standard. The amplified fragment sizes were $625 \mathrm{bp}$ for $16 \mathrm{~S}$ rRNA, 754bp for tetQ, 397bp for tetM, 458bp for $n i m, 618 \mathrm{bp}$ for $b l a_{\mathrm{TEM}}$, $255 \mathrm{bp}$ for $n и с$ ка $527 \mathrm{bp}$ for mecA. The electrophoresis for each PCR product was carried out twice in order to test the reproducibility of the method.

\section{Statistical Analyses}

The statistical analysis of the data was carried out with the statistical package SPSS 19.0 version (SPSS Inc., Chicago, IL, USA).

Differences regarding the distribution of participants, according to gender and smoking were sought by applying the z-test for proportions adjusted with Bonferroni corrections and differences between the two groups regarding mean age were sought by applying the Kruskal -Wallis test.

For clinical parameters, indicators of Descriptive Statistics were used, such as mean and standard deviation for each group, with the patient as the observational unit. Differences in clinical parameters for full-mouth periodontal recordings and investigated implants respectively, were sought by applying the Kruskal-Wallis test.

Differences in the prevalence of investigated genes were also sought between the group with healthy implants and peri-implantitis, by applying the z-test for proportions adjusted with Bonferroni corrections.

Statistical significance was set for all comparisons at the 0.05 level.

\section{RESULTS}

Demographic data for participants are presented in Table 3. Participants were age and smoking status matched, (KruskalWallis and z-test with Bonferroni corrections-tests, $p>0.05$ ).

Clinical parameters for the two groups and for investigated implants are presented in Tables $\mathbf{4}$ and $\mathbf{5}$ respectively. Groups were statistically different regarding clinical parameters of full mouth periodontal conditions (Kruskal-Wallis and z-test with Bonferroni corrections-tests, $p<0.05)$ as depicted in Table 4. Clinical parameters of investigated implants also displayed significant statistical differences between the two groups as presented in Table 5 (KruskalWallis and z-test with Bonferroni corrections-tests, $p<0.05$ ) with significant peri implant disease (mean probing depth, clinical attachment loss and bleeding on probing) in the peri implantitis group.

The distribution of investigated genes is displayed in Table 6. According to the findings of the present study, no differences were observed between the healthy implants vs peri-implantitis groups regarding the prevalence of three out of six investigated antimicrobial resistance genes. Findings have shown high frequencies of detection for both groups for the tetracycline resistance genes tetM $(>30 \%)$, tetQ $(>65 \%)$ with no statistical differences between them (z-test with Bonferroni corrections, $p<0.05)$. The $b l a_{\text {TEM }}$ gene, which encodes resistance to beta-lactams, was detected in $<15 \%$ of the samples. The nim gene, which encodes resistance to metronidazole, S.aureus and the mecA gene encoding for MRSA were not detected in any of the analyzed samples (Table 6). 
Table 5. Clinical parameters of evaluated implants.

\begin{tabular}{|c|c|c|c|c|c|}
\hline & $\mathbf{N}$ & $\begin{array}{l}\text { Probing Depth }(\mathbf{m m}) \\
\quad(\text { mean } \pm \text { SD })\end{array}$ & $\begin{array}{c}\text { Reseccion } \\
(\text { mean } \pm \text { SD })\end{array}$ & $\begin{array}{l}\text { Clinical Attachment Level } \\
\qquad \begin{array}{c}(\mathbf{m m}) \\
(\text { mean } \pm \text { SD })\end{array}\end{array}$ & $\begin{array}{c}\text { Bleeding on Probing } \\
(\%)\end{array}$ \\
\hline $\begin{array}{l}\text { Clinically healthy osseointe- } \\
\text { grated implants }\end{array}$ & 20 & $\begin{array}{l}2.1 \pm 0.5 \\
\text { (a) }\end{array}$ & $0.1 \pm 0.2$ & $\begin{array}{l}2.1 \pm 0.5 \\
\text { (b) }\end{array}$ & $\begin{array}{l}0 \\
\text { (a) }\end{array}$ \\
\hline Peri-implantitis & 20 & $\begin{array}{l}5.9 \pm 1 \\
\text { (a) }\end{array}$ & $-0.5 \pm 1.3$ & $\begin{array}{l}5.4 \pm 1.7 \\
\text { (b) }\end{array}$ & $\begin{array}{l}88 \% \pm 20 \% \\
\text { (a) }\end{array}$ \\
\hline
\end{tabular}

Statistically significant differences between groups are indicated by the same letter (Kruskal -Wallis test and $\mathrm{z}$-test with Bonferroni corrections, $\mathrm{p}<0.05$ )

Table 6. Frequency of detection of tetM, tetQ, bla ${ }_{\mathrm{TEM}}$, nim, Staphylococcus aureus and mecA in evaluated implants.

\begin{tabular}{|c|c|c|c|c|c|c|c|}
\hline & $\mathbf{N}$ & $\begin{array}{c}\text { tetM } \\
\% \\
\text { (positive/total) }\end{array}$ & $\begin{array}{c}\text { tetQ } \\
\% \\
\text { (positive/total) }\end{array}$ & $\begin{array}{c}\boldsymbol{b l a}_{\mathrm{TEM}} \\
\% \\
\text { (positive/total) }\end{array}$ & $\begin{array}{c}\text { nim } \\
\% \\
\text { (positive/total) }\end{array}$ & $\begin{array}{c}\text { S.aureus } \\
\% \\
\text { (positive/total) }\end{array}$ & $\begin{array}{c}\text { mecA } \\
\% \\
\text { (positive/total) }\end{array}$ \\
\hline $\begin{array}{l}\text { Participants with clinically } \\
\text { healthy osseointegrated } \\
\text { implants }\end{array}$ & 20 & $\begin{array}{c}30 \% \\
(6 / 20)\end{array}$ & $\begin{array}{c}65 \% \\
(13 / 20)\end{array}$ & $\begin{array}{c}15 \% \\
(3 / 20)\end{array}$ & $0 \%$ & $0 \%$ & $0 \%$ \\
\hline Total & 40 & $35 \%$ & $70 \%$ & $10 \%$ & $0 \%$ & $0 \%$ & $0 \%$ \\
\hline
\end{tabular}

No differences were observed between groups (z-test for proportions with Bonferroni corrections, $\mathrm{p}>0.05$ )

\section{DISCUSSION}

Peri-implant diseases and their effective treatment pose an increasing clinical challenge. Studies regarding the incidence of peri-implant mucositis have reported that up to $48 \%$ of implants in a follow-up period of up to 14 years can be affected by this condition which can be both preventable and reversible once early diagnosed [23].

In contrast, the reported prevalence of peri-implantitis presents distinct differences, attributed mainly to the variety of clinical and radiographic thresholds set for the disease.

Regarding the etiology and pathogenetic mechanisms, it is currently accepted, that peri-implant diseases are infectious in nature, similar to periodontal diseases and occur as the result of an imbalance between the bacterial challenge and host response. At the present time, Gram-negative anaerobic species known consensus pathogens for periodontitis, have also been associated with peri-implantitis. Thus, members of the "red complex" as described by Socransky et al.1998, including Porphyromonas gingivalis, Treponema denticola and Tanerella forsythia, along with Gram-negative anaerobes such as Prevotella and Fusobacterium spp, have been shown to be present in peri-implantitis lesions [24]. It should be noticed that species not known to clearly be involved in periodontal pathology such as Staphylococcus aureus, have been associated to correlate with the initiation of peri-implantitis $[23,25,26]$.
The implication of $S$. aureus and MRSA in peri-implant pathology is not supported by findings of the present study, albeit the limited subject sample since neither was detected in any of the investigated samples. Nevertheless it should be kept in mind that the aetiopathological significance of species such as Candida albicans, Gram-negative enteric rods and Staphylococci spp remains unclear and more studies are required [25].

Previous studies, displaying the presence of Staphylococcus spp and S. aureus in peri-implant lesions, by applying cultural techniques, reported that participants had previously used antibiotics [27]. Therefore, findings of the present study are not comparable with the above mentioned data, since according to criteria of inclusion of the study, subjects have not been administered antibiotics for at least 6 months prior to enrollment. The findings are also in agreement with previous studies, which reported that when Staphylococci spp have been detected in peri-implantitis lesions, they belonged mainly to the species S. epidermidis and not to S.aureus $[26,28]$.

According to findings of the present study, the genes encoding for resistance to the tetracyclines were detected in high frequencies in the subject sample irrelevant of periimplant conditions (> $30 \%$ for tetM and $>65 \%$ for tet $Q$ ). These genes have been shown to correlate with Grampositive non pathogenic species and Gram-negative 
periodontal pathogens respectively $[16,17]$. These high frequencies of detection might suggest that this class of antibiotics is not suitable for treating peri-implant infection. Previous studies in the literature have generally positive effects in clinical parameters of peri-implant lesions after local administration of tetracycline's [29-32], but the outcome is generally unpredictable for all patients and further clinical trials are required and no data exist in the literature regarding the effect of antimicrobial resistance in the outcome of these treatments.

The $b l a_{\mathrm{TEM}}$ gene, which encodes for resistance to the beta-lactams, was detected, according to present findings, in much lower frequencies compared to tet $M$ and tet $Q$ in investigated samples (15\% from healthy implants and 5\% for periimplantis cases respectively). These findings support the use of this class of antibiotics for treatment of peri-implant infections. In addition, the fact that the nim gene, which encodes for resistance to metronidazole, was not detected in any of investigated samples supports the administration of this antibiotic alone or in combination with beta-lactams for resolution of peri-implantitis.

Limitations of the current pilot study include the confined subject sample and the fact that cultural techniques such as antibiotic sensitivity were not applied and therefore the bacterial source of investigated antibiotic resistance genes cannot be identified. However it is known that the biofilm structure of bacterial accumulations in the oral cavity allows for the dissemination of genetic material between different microbial species and even genera [12, 13, 33].

Thus, taking the above mentioned findings into account, the administration of tetracyclines for treatment of periimplant diseases might be compromised due to the high prevalence of detection of genes encoding resistance to these antibiotics. In contrast, data regarding the $b l a_{\mathrm{TEM}}$ gene suggest that beta-lactams could be effective in treating periimplantitis as an infection. The same is suggested for metronidazole, as an antimicrobial for treating Gram-negative infections or the combination of the two antibiotics.

\section{CONCLUSION}

Healthy peri-implant sulci and peri-implantitis cases often harbor bacterial genes encoding for resistance to the tetracyclines and less often for beta-lactams. Thus, the antimicrobial activity of the tetracyclines and to a lower extent of beta-lactams, might be compromised for treatment of periimplantitis. Since no metronidazole resistance genes were detected in the present study, its clinical use is supported by the current findings. S.aureus may not participate in periimplant pathology since it was not detected in any of the investigated samples.

\section{CONFLICT OF INTEREST}

The authors confirm that this article content has no conflicts of interest.

\section{ACKNOWLEDGEMENTS}

This research has been partly co-financed by the European Union (European Social Fund - ESF) and Greek national funds through the Operational Program "Education and Lifelong Learning" of the National Strategic Reference Framework (NSRF) - Research Funding Program: Heracletus II. Investing in knowledge society through the European Social Fund. The authors declare no potential conflicts of interest with respect to the authorship and/or publication of this article.

\section{REFERENCES}

[1] Jung RE, Zembic A, Pjetursson BE, Zwahlen M, Thoma DS. Systematic review of the survival rate and the incidence of biological, technical, and aesthetic complications of single crowns on implants reported in longitudinal studies with a mean follow-up of 5 years. Clin Oral Implants Res 2012; 23 (6): 2-21.

[2] Pjetursson BE, Thoma D, Jung R, Zwahlen M, Zembic A. A systematic review of the survival and complication rates of implantsupported fixed dental prostheses (FDPs) after a mean observation period of at least 5 years. Clin Oral Implants Res 2012; 23 (6): 2238 .

[3] Zitzmann NU, Berglundh T. Definition and prevalence of periimplant diseases. J Clin Periodontol 2008; 35(8): 286-91.

[4] Koldsland OC, Scheie AA, Aass AM. Prevalence of periimplantitis related to severity of the disease with different degrees of bone loss. J Periodontol 2010; 81(2): 231-8.

[5] Mombelli A, Décaillet F. The characteristics of biofilms in periimplant disease. J Clin Periodontol 2011; 38 (11): 203-13.

[6] Lang NP, Berglundh T. Peri-implant diseases:Where are we now?Concensus of the Seventh European Workshop on Periodontology. J Clin Periodontol 2011; 38 (11): 182-7.

[7] Lindhe J, Meyle J. Group D of European Workshop on Periodontology. Peri-implant diseases: Consensus Report of the Sixth European Workshop on Periodontology. J Clin Periodontol 2008. 35:. 282-5.

[8] Renvert S, Roos-Jansåker A-M, Claffey N. Non-surgical treatment of peri-implant mucositis and peri-implantitis: a literature review. J Clin Periodontol 2008; 35(8): 305-15.

[9] van Winkelhoff AJ. Antibiotics in the treatment of peri-implantitis. Eur J Oral Implantol 2012; 5:S43-50.

[10] Heitz-Mayfield LJA, Mombelli A. The therapy of peri-implantitis: a systematic review. Int J Oral Maxillofac Implants 2014; 29: 32545 .

[11] World Health Organization. The evolving threat of antimicrobial resistance. Geneva 2012

[12] Roberts AP, Pratten J, Wilson M, Mullany P. Transfer of a conjugative transposon, Tn5397 in a model oral biofilm. FEMS Microbiol Lett 1999; 177(1): 63-6.

[13] Warburton PJP, Palmer RMR, Munson MAM, Wade WGW. Demonstration of in vivo transfer of doxycycline resistance mediated by a novel transposon. J Antimicrob Chemother 2007; 60(5): 973-80.

[14] Ioannidis I, Sakellari D, Spala A, Arsenakis M, Konstantinidis A. Prevalence of tetM, tetQ, nim and bla(TEM) genes in the oral cavities of Greek subjects: a pilot study. J Clin Periodontol 2009; 36(7): 569-74.

[15] Goncharoff PP, Figurski DHD, Stevens RHR, Fine DHD. Identification of Actinobacillus actinomycetemcomitans: polymerase chain reaction amplification of lktA-specific sequences. Oral Microbiol Immunol 1993; 8(2):105-10.

[16] Lacroix JM, Walker CB. Detection and incidence of the tetracycline resistance determinant tet(M) in the microflora associated with adult periodontitis. J Periodontol 1995; 66(2):102-8.

[17] Lacroix JM, Walker CB. Detection and prevalence of the tetracycline resistance determinant Tet $\mathrm{Q}$ in the microbiota associated with adult periodontitis. Oral Microbiol Immunol 1996; 11(4): 2828. 
[18] Alsultan AA, Aboulmagd E, Amin TT. ESBL-producing E. coli and K. pneumoniae in Al-Ahsa, Saudi Arabia: antibiotic susceptibility and prevalence of blaSHV and blaTEM. J Infect Dev Ctries 2013; 7(12):1016-9.

[19] Trinh S, Reysset G. Detection by PCR of the nim genes encoding 5-nitroimidazole resistance in Bacteroides spp. J Clin Microbiol 1996; 34(9): 2078-84.

[20] Poulsen AB, Skov R, Pallesen LV. Detection of methicillin resistance in coagulase-negative staphylococci and in staphylococci directly from simulated blood cultures using the EVIGENE MRSA Detection Kit. J Antimicrob Chemother 2003; 51(2): 419-21.

[21] Salisbury SM, Sabatini LM, Spiegel CA. Identification of methicillin-resistant staphylococci by multiplex polymerase chain reaction assay. Am J Clin Pathol 1997; 107(3): 368-73.

[22] Koukos G, Sakellari D, Arsenakis M, Tsalikis L, Slini T, Konstantinidis A. Prevalence of tetracycline resistance genes in the oral cavity of Greek subjects. J Biol Res-Thessalon 2013; 20: 387-94.

[23] AAP. Peri-implant mucositis and peri-implantitis: a current understanding of their diagnoses and clinical implications. J Periodontol 2013; 84(4): 436-43.

[24] Socransky SS, Haffajee AD, Cugini MA, Smith C, Kent RL. Microbial complexes in subgingival plaque. J Clin Periodontol 1998; 25(2): 134-44.

[25] Heitz-Mayfield LJA, Lang NP. Comparative biology of chronic and aggressive periodontitis vs. peri-implantitis. Periodontol 2000 2010; 53: 167-81.
[26] Leonhardt AA, Renvert SS, Dahlén GG. Microbial findings at failing implants. Clin Oral Implants Res 1999; 10(5): 339-45.

[27] Rams TE, Feik D, Slots J. Staphylococci in human periodontal diseases. Oral Microbiol Immunol 1990; 5(1): 29-32.

[28] Rosenberg ES, Torosian JP, Slots J. Microbial differences in 2 clinically distinct types of failures of osseointegrated implants. Clin Oral Implants Res 1991; 2(3): 135-44.

[29] Mombelli A, Feloutzis A, Brägger U, Lang NP. Treatment of periimplantitis by local delivery of tetracycline. Clinical, microbiological and radiological results. Clin Oral Implants Res 2001; 12(4): 287-94.

[30] Renvert S, Lessem J, Dahlén G, Lindahl C, Svensson M. Topical minocycline microspheres versus topical chlorhexidine gel as an adjunct to mechanical debridement of incipient peri-implant infections: a randomized clinical trial. J Clin Periodontol 2006; 33(5): 362-9.

[31] Salvi GE, Persson GR, Heitz-Mayfield LJA, Frei M, Lang NP. Adjunctive local antibiotic therapy in the treatment of periimplantitis II: clinical and radiographic outcomes. Clin Oral Implants Res 2007; 18(3): 281-5.

[32] Büchter A, Meyer U, Kruse-Lösler B, Joos U, Kleinheinz J. Sustained release of doxycycline for the treatment of peri-implantitis: randomised controlled trial. Br J Oral Maxillofac Surg 2003; 42(5): 439-44.

[33] Hausner M, Wuertz S . High rates of conjugation in bacterial biofilms as determined by quantitative in situ analysis. Appl Environ Microbiol 1999; 65: 3710-13.

(c) Koukos et al.; Licensee Bentham Open.

This is an open access article licensed under the terms of the Creative Commons Attribution Non-Commercial License (http://creativecommons.org/licenses/by-nc/3.0/) which permits unrestricted, non-commercial use, distribution and reproduction in any medium, provided the work is properly cited. 